\title{
Long-term increase of March temperature has no negative impact on tree rings of European larch (Larix decidua) in lowland Poland
}

\author{
Marcin Koprowski
}

Received: 13 April 2012/Revised: 21 June 2012 / Accepted: 10 July 2012/Published online: 4 August 2012

(C) The Author(s) 2012. This article is published with open access at Springerlink.com

\begin{abstract}
European larch trees grown outside their natural range were intensively studied in terms of their adaptability to increased late winter temperature. A total of 264 cores of larch were taken from 12 sites throughout northern Poland at sites outside of its natural range. Clustering of de-trended chronologies reveal that research sites are grouped geographically. The mean ring widths, however, are similar amongst the four regions. In total, $21 \%$ of the single correlations for all months for tree-ring widths were significant at the $5 \%$ error level. For earlywood and latewood, the figures are 18 and $19 \%$, respectively. A generally positive precipitation effect was found, however, no significant negative effect was observed. Temperature had mixed effects on ring width. Higher temperatures in late winter and early spring increased ring width in region 2 . High summer temperatures in both the previous and the current year, on the other hand, generally had a negative impact on tree-ring width during the growing season. On most of the sites, the observed long-term trend for increasing temperatures in March had no significant negative influence on tree growth. The visual condition of European larch together with the lack of any negative response of tree rings to observed March temperature increase suggest that it may be beneficial to introduce this species into new areas.
\end{abstract}

Communicated by M. Zwieniecki.

M. Koprowski ( $\square)$

Laboratory of Dendrochronology, Faculty of Biology

and Environment Protection, Institute of Ecology

and Environment Protection, Nicolaus Copernicus University,

Gagarina 9, 87-100 Torun, Poland

e-mail: koper@umk.pl
Keywords Dendrochronology · Dendroclimatology · European larch · Larix decidua · Tree rings .

Environmental change

\section{Introduction}

The changes in climate have been well documented recently. At a global scale, warming and widespread changes in land use have been established (Solomon et al. 2007). A significant increase in March temperature has been shown in Poland (Kożuchowski and Degirmendžić 2005), and in addition, other factors related to vegetation have been changed. For example, there has been a change in the vegetational thermal season towards beginning of, or shortened cold periods during the winter, with warmer temperatures beginning earlier in the spring (Kożuchowski and Degirmendžić 2005). The temperature during the last days of winter and the beginning of spring is crucial for cambial activity. The dendroclimatological research in northern Poland using Scots pine (Pinus sylvestris) emphasised that February and March air temperature is the most important factor limiting pine growth (Zielski et al. 2010). February and March air temperature also plays an important role in the Małopolska Region (Lesser Poland) (Szychowska-Krapiec 2010), Lower Silesia, and the Sudety mountains (Feliksik and Wilczyński 2000; Wilczyński and Skrzyszewski 2002). The impact of temperature during February and March is so important that long-term chronologies are used to reconstruct the climate in the area of North (Koprowski et al. 2012) and South Poland (Szychowska-Krapiec 2010). For Norway spruce growing within its natural range in the south-eastern part of Poland, March temperature seems to be one of the most important factors in determining tree growth (Koprowski and Zielski 
2006). Silver fir growing in northern Poland is also sensitive to thermal conditions in March (Koprowski and Gławenda 2007; Bijak 2010). However, fir from the Świętokrzyskie Mountains shows the reverse, a negative relationship between growth and March temperature (Bronisz et al. 2010).

The impact of higher temperatures in March on the growth and health status of larch is still insufficiently understood. Because larch is one of the most important tree species in Polish forests, there is clearly a need for knowledge about the impact of climate change on the ecology and growth of this species. As a fast-growing tree, it can also be a potential plant for biomass production in Poland (Igliński et al. 2011).

The present work therefore has four major aims:

1. To identify the climate parameters that affect the growth of larch outside its natural range and to compare these patterns to those found for trees within its natural range. The latter is already sufficiently known for many natural stands (Büntgen et al. 2007; Danek and Danek 2011; Frank and Esper 2005; Carrer and Urbinati 2004, 2006; Kirdyanov et al. 2008).

2. To identify homogenous regions that are similar in growth pattern. The spatial distribution of increment patterns allows homogenous regions to be recognised and generalisations about the climate requirements for non-native species in each area to be made. This strategy was also applied for spruce and gave promising results (Koprowski 2012) and such differences also have implications for historical dating strategies.

3. To investigate how climate-growth relationships change over the time. D'Arrigo et al. (2008) linked this change to anthropogenic factors while Schweingruber (1996) pointed to general changes in environmental conditions. The early onset of spring (Kożuchowski and Degirmendžić 2005) may influence patterns of tree growth in a similar way to those observed for changing June-July temperature in Alaska (D'Arrigo et al. 2008).

4. The study of trees outside the natural range might help to decide how larch reacts after introduction and possibly how it reacts to climate change. Furthermore, it may help answer the question, 'is the further introduction of European larch outside its natural range economically justified?' Interestingly the ages of Polish larches reveal that most were planted outside their natural range at the end of nineteenth and at the beginning of twentieth century. Therefore, the data presented span at least 80 years and allow for a detailed comparison of tree growth and weather conditions.

\section{Materials and methods}

Materials

A total of 264 cores of European larch were taken from 12 sites (Fig. 1) throughout North Poland at sites outside or at the border of its natural range. The sites belong to the Polish lowland and have sub-Atlantic vegetation with a predominantly oceanic climate. The mean yearly precipitation ranges between 450 and $700 \mathrm{~mm}$, and the mean yearly temperature range is $7-9{ }^{\circ} \mathrm{C}$. By comparison, the natural range has a more continental climate with pronounced temperature differences between summer and winter.

\section{Chronology development}

Two core samples were taken from each tree, one from the west and one from the east, using a Pressler borer, at a height of approximately $1.30 \mathrm{~m}$ above ground. The cores were prepared for measurement using standard dendrochronological procedures (Zielski and Krạpiec 2004). Basic tree-ring parameters were obtained from the measurement of ring widths to the nearest $0.01 \mathrm{~mm}$ using CooRecorder software combined with the related CDendro program (http://www.cybis.se). Checks on cross-matching were carried out using COFECHA (Grissino-Mayer 2001). In addition, each sample was analysed by means of the skeleton plot method (Schweingruber 1996). Both the skeleton plot method and the results from the COFECHA programme were used for evaluating and detecting narrow and wide rings. De-trending of the chronology was done with the dplR software (Bunn 2008) using the smoothing spline option, which reflects trends in the chronology better than other options. The " $n$-year spline" was fixed at $2 / 3$ the wavelength of $n$ years (Cook et al. 1990). The residual version of the chronology was built by pre-whitening, performed by fitting an autoregressive model to the data with AIC model selection (Bunn 2008).

Hierarchical cluster analysis (Ward method) was used as implemented in the amap R package (Author: Lucas) to separate the tree-ring series from each site and to distinguish regions with similar increment patterns (Wilson and Hopfmueller (2001). The idea of hierarchical clustering (Ward method) is to maximise the between-group variance, while minimising the within-group variance (Ward 1963). Pearson's correlation coefficient was used as a measure of similarity. The March temperature increase was investigated using the bootstrap running correlation option with a 25 year shifting window (package bootRes, Author: Zang). 
Fig. 1 Locations of the research sites (filled circle) and meteorological stations $(x)$ with climatic regions in Poland (according to Okołowicz and Martyn 1984). Numbers of research sites and letters of meteorological stations correspond to those in Table 1
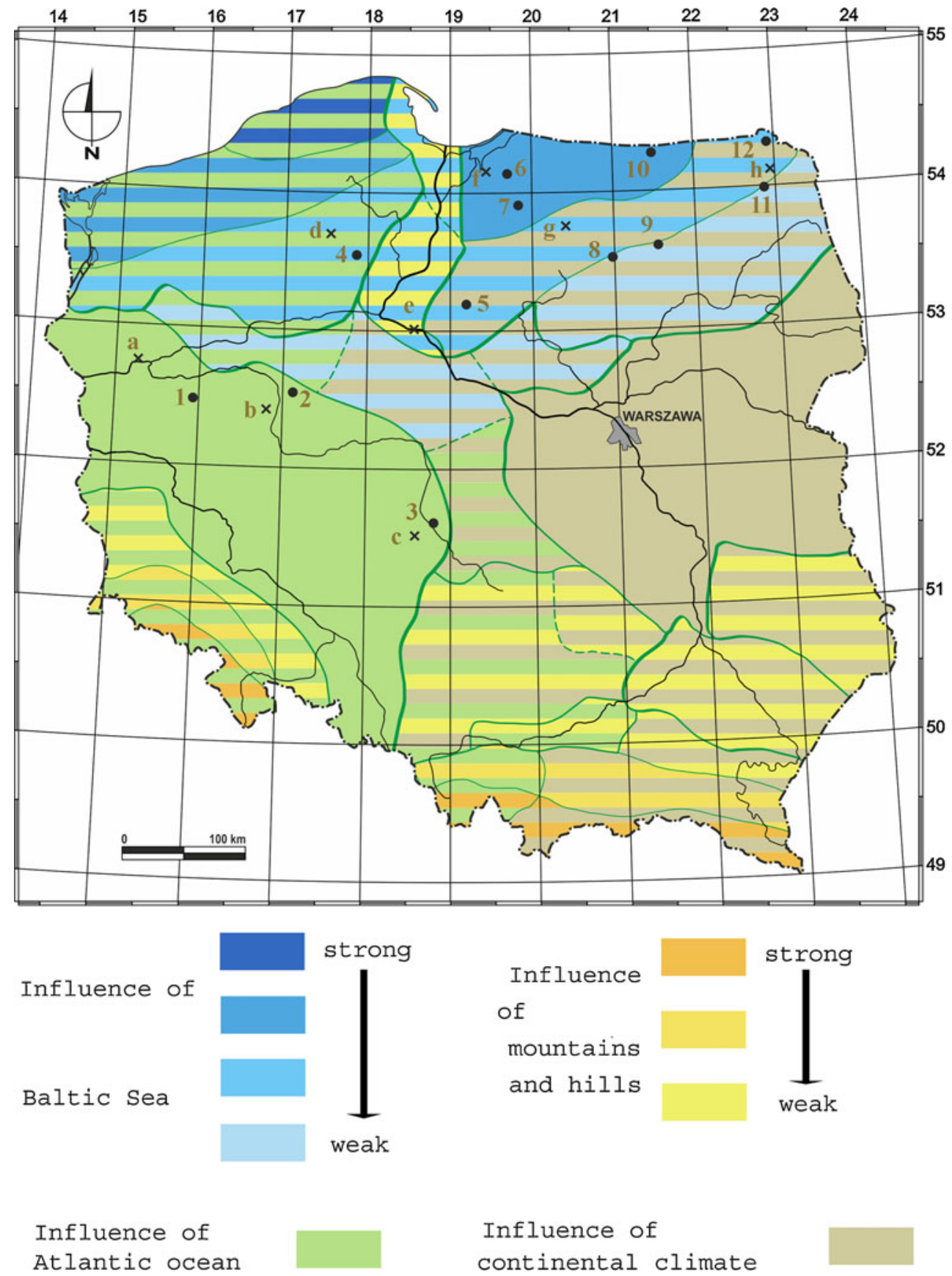

Influence of
Atlantic ocean

Dendroclimatological analysis

Mean monthly temperature and total monthly precipitation for selected meteorological stations in Poland came from the European Climate Assessment and Dataset (ECA\&D) project (Klein Tank et al. 2002). For each research site, the climate data were taken from the nearest meteorological station, or mean values were counted for stations at a similar distance from the research site (Fig. 1; Table 1).
Figure 2 shows the linear trend for March temperature increase.

In order to investigate climate/growth relationships, the DendroCLIM 2002 software was applied (Biondi and Waikul 2004) using a bootstrap procedure to estimate the error. Climate data from May (previous year) to September (current year) served as independent variables and the residual chronologies for each site were used as dependent variables. 
Table 1 Locations of the research sites

\begin{tabular}{|c|c|c|c|c|c|c|}
\hline \multirow{2}{*}{$\begin{array}{l}\text { Site } \\
\text { number }\end{array}$} & \multirow{2}{*}{$\begin{array}{l}\begin{array}{l}\text { Forest } \\
\text { inspectorate }\end{array} \\
\text { Barlinek }\end{array}$} & \multirow{2}{*}{$\begin{array}{l}\text { Region } \\
\text { Region } 1\end{array}$} & \multicolumn{2}{|c|}{ Geographical position } & \multirow{2}{*}{$\begin{array}{l}\text { Forest site } \\
\text { Ff }\end{array}$} & \multirow{2}{*}{$\begin{array}{l}\text { Meteorological station, } \\
\text { elevation (m.a.s.l.), geographical position }\end{array}$} \\
\hline & & & $\varphi \mathrm{N} 52^{\circ} 58^{\prime} 01.8^{\prime \prime}$ & $\lambda \mathrm{E} 15^{\circ} 15^{\prime} 21.7^{\prime \prime}$ & & \\
\hline 2 & Łopuchówko & & $\varphi \mathrm{N} 52^{\circ} 32^{\prime} 58.3^{\prime \prime}$ & $\lambda \mathrm{E} 17^{\circ} 07^{\prime} 42.8^{\prime \prime}$ & Fmf & b. Gorzów Wielkopolski, $72, \varphi \mathrm{N} 52^{\circ} 45^{\prime}, \lambda \mathrm{E} 15^{\circ} 16^{\prime}$ \\
\hline 3 & Sieradz & Region 2 & $\varphi \mathrm{N} 51^{\circ} 36^{\prime} 44.5^{\prime \prime}$ & $1 \lambda \mathrm{E} 8^{\circ} 48^{\prime} 36^{\prime \prime}$ & $\mathrm{Ff}$ & c. Wieluń, $195, \varphi \mathrm{N} 51^{\circ} 31^{\prime}, \lambda \mathrm{E} 18^{\circ} 35^{\prime}$ \\
\hline 4 & Tuchola & Region 3 & $\varphi \mathrm{N} 53^{\circ} 33^{\prime} 22^{\prime}$ & $\lambda \mathrm{E} 17^{\circ} 51^{\prime} 44^{\prime \prime}$ & Fmf & d. Chojnice, $172, \varphi \mathrm{N} 53^{\circ} 42^{\prime}, \lambda \mathrm{E} 17^{\circ} 33^{\prime}$ \\
\hline 5 & Golub Dobrzyń & & $\varphi \mathrm{N} 53^{\circ} 11^{\prime} 50.8^{\prime \prime}$ & $\lambda \mathrm{E} 19^{\circ} 11^{\prime} 50.0^{\prime \prime}$ & $\mathrm{Ff}$ & 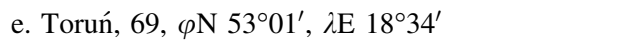 \\
\hline 6 & Młynary & Region 4 & $\varphi \mathrm{N} 54^{\circ} 09^{\prime} 7^{\prime \prime}$ & $\lambda \mathrm{E} 19^{\circ} 41^{\prime} 17.9^{\prime \prime}$ & $\mathrm{Ff}$ & f. Elbląg, $38, \varphi \mathrm{N} 54^{\circ} 10^{\prime}, \lambda \mathrm{E} 19^{\circ} 26^{\prime}$ \\
\hline 7 & Dobrocin & & $\varphi \mathrm{N} 53^{\circ} 55^{\prime} 12.1^{\prime \prime}$ & $\lambda \mathrm{E} 19^{\circ} 50^{\prime} 41.7^{\prime \prime}$ & $\mathrm{Ff}$ & g. Olsztyn, $133, \varphi \mathrm{N} 53^{\circ} 46^{\prime}, \lambda \mathrm{E} 20^{\circ} 25^{\prime}$ \\
\hline 8 & Szczytno & & $\varphi \mathrm{N} 53^{\circ} 32^{\prime} 11.1^{\prime \prime}$ & $\lambda \mathrm{E} 20^{\circ} 58^{\prime} 32.6^{\prime \prime}$ & $\mathrm{Ff}$ & h. Suwałki, $184, \varphi \mathrm{N} 54^{\circ} 08^{\prime}, \lambda \mathrm{E} 22^{\circ} 57^{\prime}$ \\
\hline 9 & Maskulińskie & & $\varphi \mathrm{N} 53^{\circ} 36^{\prime} 57^{\prime \prime}$ & $\lambda \mathrm{E} 21^{\circ} 32^{\prime} 34^{\prime \prime}$ & $\mathrm{Ff}$ & \\
\hline 10 & Srokowo & & $\varphi \mathrm{N} 54^{\circ} 17^{\prime} 20.3^{\prime \prime}$ & $\lambda \mathrm{E} 21^{\circ} 28^{\prime} 50.4^{\prime \prime}$ & $\mathrm{Ff}$ & \\
\hline 11 & Szczebra & & $\varphi \mathrm{N} 54^{\circ} 00^{\prime} 06.2^{\prime \prime}$ & $\lambda$ E $22^{\circ} 51^{\prime} 56.3^{\prime \prime}$ & $\mathrm{Ff}$ & \\
\hline 12 & Suwałki & & $\varphi \mathrm{N} 54^{\circ} 19^{\prime} 38.2^{\prime \prime}$ & $\lambda \mathrm{E} 22^{\circ} 54^{\prime} 58.3^{\prime \prime}$ & $\mathrm{Ff}$ & \\
\hline
\end{tabular}

The sites (numbers) correspond to those in Figs. 1 and 3 and meteorological stations (letters) to those in Fig. 1

$F f$ fresh forest, $F m f$ fresh mixed forest

Fig. 2 The increase in March temperature in each region

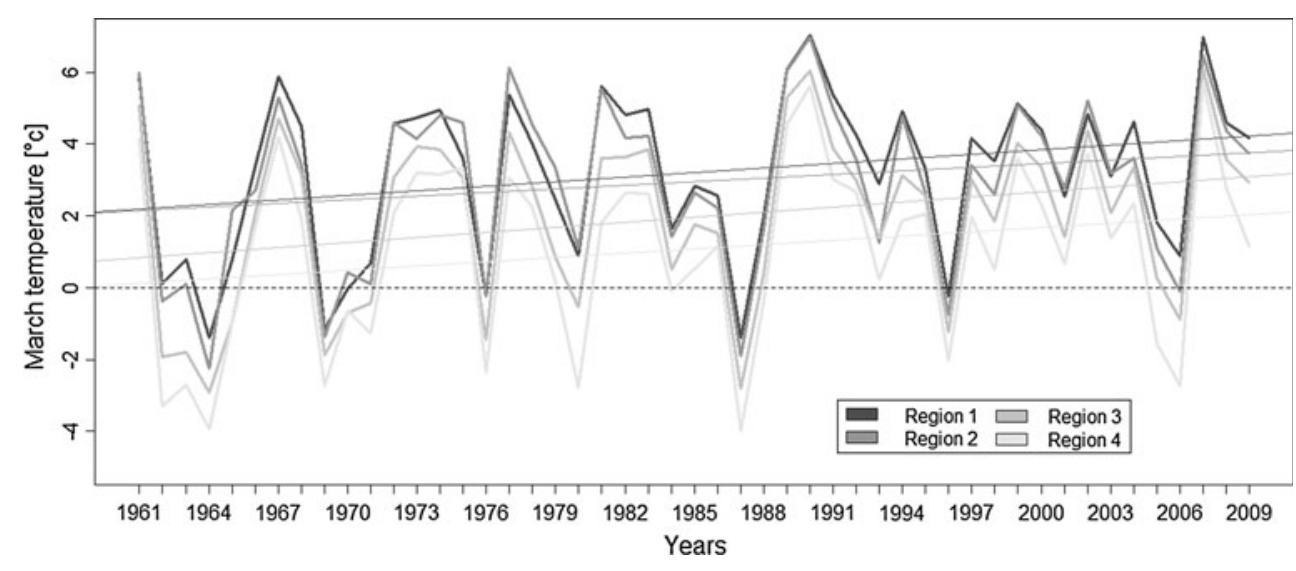

\section{Results}

Tree-ring parameter chronologies

The longest chronology for the selected regions was derived from region 1 and covers the years 1814-2009 (Table 2), the oldest trees grow in a natural reserve in the Łopuchówko forest inspectorate. The average tree-ring width varies between regions, ranging from $1.57 \mathrm{~mm}$ to $1.93 \mathrm{~mm}$ (Table 2). The portion of the latewood (LW) in the whole tree-ring width (TRW) is comparable and varies from $33 \%$ (region 4) to $38 \%$ (region 1). The Rbar and EPS of TRW varied from 0.512 to 0.766 , and from 0.904 to 0.969 , respectively (Table 2) and were above the frequently applied threshold of 0.85 , indicating robust mean value functions (Wigley et al. 1984) and such EPS values suggest the sample size is adequate (McCarroll and Loader 2004). Furthermore, the values of EPS for latewood and earlywood suggest that the common signal in LW and EW is reliable for dendroclimatic study.

The hierarchical cluster analysis identified four distinct regions of larch in the basis of tree-ring widths (Fig. 3; Table 1). The first and second region are characterised by a maritime climate (sites 1-3). The third region is a mixture of continental, Atlantic, and Baltic climate aspects. The fourth region in northeastern Poland is under the influence of the Baltic Sea (sites 6, 7, and 10) and mixture of continental and Baltic climate aspects (sites 8, 9, 11, and 12).

\section{Climate response}

The effect of temperature of the previous year on tree-ring widths, latewood and earlywood in the current year is comparable (Fig. 4). The cross-correlation between the responses of TRW, EW, $\mathrm{LW}$ and the temperature in the previous year varied from $0.99(p<0.001)$ to 0.41 
Table 2 Descriptive statistics for arithmetic means in each region

\begin{tabular}{|c|c|c|c|c|c|}
\hline & Series & Period & $\begin{array}{l}\text { Mean measurement } \\
(\mathrm{mm})\end{array}$ & $\begin{array}{l}\text { Rbar } \\
\text { effective }\end{array}$ & EPS \\
\hline \multicolumn{6}{|c|}{ Region 1} \\
\hline TRW & 34 & 1814-2009 & 1.57 & 0.730 & 0.957 \\
\hline EW & & & 1.01 & 0.706 & 0.951 \\
\hline LW & & & 0.56 & 0.674 & 0.944 \\
\hline \multicolumn{6}{|c|}{ Region 2} \\
\hline TRW & & & 1.69 & 0.632 & 0.943 \\
\hline EW & 20 & 1898-2009 & 1.08 & 0.598 & 0.934 \\
\hline LW & & & 0.61 & 0.602 & 0.935 \\
\hline \multicolumn{6}{|c|}{ Region 3} \\
\hline TRW & & & 1.93 & 0.512 & 0.904 \\
\hline EW & 27 & 1863-2009 & 1.27 & 0.494 & 0.897 \\
\hline LW & & & 0.66 & 0.435 & 0.873 \\
\hline \multicolumn{6}{|c|}{ Region 4} \\
\hline TRW & & & 1.90 & 0.766 & 0.969 \\
\hline EW & 121 & 1832-2006 & 1.27 & 0.743 & 0.965 \\
\hline LW & & & 0.63 & 0.668 & 0.951 \\
\hline
\end{tabular}

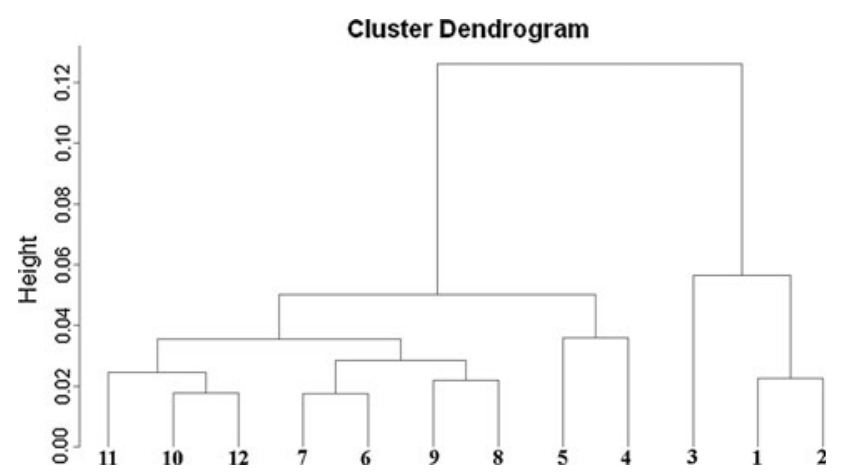

Fig. 3 Dendrogram of the results of cluster analysis. Numbers of research sites and letters of meteorological stations correspond to those in Table 1

$(p<0.5)$. The difference is between response of LW and EW. The latewood is less sensitive to increased temperature in the previous October (Fig. 4). TRW and EW react negatively to high temperature in the previous July, August, and September. The reaction on temperature in the current growth season is less homogenous (Fig. 4). The highest correlation is between regions 2 and 4 for TRW and EW, $0.784(p<0.05)$ and $0.768(p<0.05)$, respectively. For LW, it is between region 2 and $3(0.841, p<0.005)$.

The relationship between tree growth and precipitation varies between the regions (Fig. 4). In the previous years, the highest correlation is between regions 1 and 3 for TRW (0.699, $p<0.1)$, EW $(0.778, p<0.05)$, and LW $(0.596$, $p<0.5)$. The reaction to the monthly sum of precipitation in the current year is more comparable between regions; the highest values of correlation for TRW (0.798, $p<0.01)$ and LW $(0.896, p<0.005)$ are between region 1 and 2. In EW a similar reaction was found between region 2 and $4(0.723, p<0.05)$. The differences between TRW, $\mathrm{EW}$, and LW from the same region are not great, however the correlation between EW and LW is lower (0.493).

Effect of March temperature

The positive effect of high March temperature is observed in region 2 for TRW and LW (Fig. 4). The lowest correlation is noted for region 1 (Fig. 4). The bootstrap running correlation with a 25 year shifting window revealed a decreasing impact of late winter temperatures, especially for TRW and EW in region 3, where the highest impact was observed for the years 1963-1989 (Fig. 5). In the last 20 years, the influence of March temperature on tree-ring widths and earlywood is stable and does not reveal a positive or negative effect. For latewood (LW), the influence of March temperature is slightly negative, especially for the period 1977-2001, reaching minimum values for the years 1981-2005. After this period, the correlation increases, but does not reach positive values (Fig. 5).

\section{Discussion}

Tree rings, earlywood, latewood and climate effect

The influence of climate on European larch tree rings growing outside their natural range differs from other coniferous species. There is a clear negative response to the temperature of the previous summer on TRW, and EW. The observed significant positive influence of March 

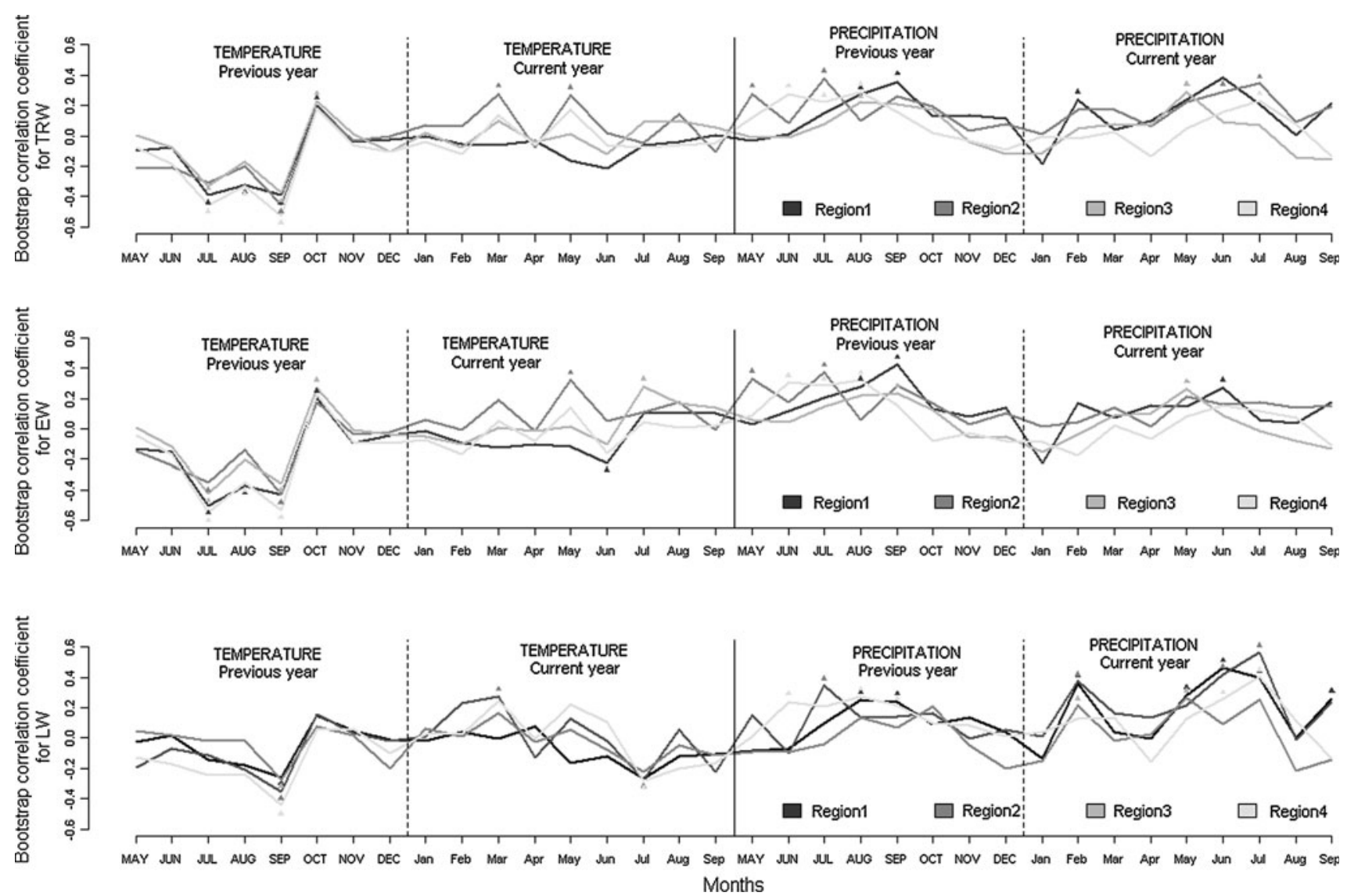

Fig. 4 Climate/growth relationships in each region. $T R W$ tree-ring widths, $E W$ earlywood, $L W$ latewood

temperature in region 2 is not so clearly visible in other regions (Fig. 4). Thermal conditions of the current year are most important in July for latewood (LW). In contrast to the Puławy (Poland) experimental plot (Oleksyn and Fritts 1991), the inverse relationship between the temperature in the previous year is not surprising. Vitas and Žeimavičius (2010) analysing pointer years revealed that the growth pattern of European larch is similar to that in Norway spruce, and this research supports that observation in some areas. The visible similarity is between the inverse response to the previous summer temperature; however, the impact of winter is not so clear. Spruce is more sensitive to low temperatures in February and March (Koprowski 2012) while the larch is more resistant. The studies from southern Poland (Danek 2009) and from Puławy (Oleksyn and Fritts 1991), in central part of eastern Poland, confirm that late winter temperature is not a crucial factor in determining the tree-ring width in larch. The latewood width (LW) of larch trees growing outside their natural range was more dependent on September temperature than on other summer months (Fig. 4). In southern Poland, the effect of current summer temperature was significant (Danek 2009). Because European larch grows naturally in mountainous regions, most of the research is from this area.
Trees from the Italian Alps (2,000-2,200 m above sea level) of similar age distribution (Carrer and Urbinati 2004) revealed that high maximum March and April temperatures have a negative effect on tree growth, in contrast to the observed positive response in June and July. In the Tatra mountains $(1,450 \mathrm{~m}$ a.s.1.), a significant influence of temperature was found in May (Büntgen et al. 2007) and in the European Alps, in May to July (Frank and Esper 2005). The positive effect of increased precipitation is visible in the vegetation season of both the previous and the current years. However, the significance of particular months varies between the regions. There is a clear difference between the reaction of LW and EW in the current summer. Latewood is more sensitive to the amount of rainfall in summer months. Trees from other parts of Poland react more clearly to precipitation in the current growing season (Oleksyn and Fritts 1991; Danek 2009). In the Alps and Tatra mountains, the higher mean values of yearly rainfall at $1,186-1,288 \mathrm{~mm}$ and $849 \mathrm{~mm}$ respectively, mean that precipitation is not the limiting factor to growth (Büntgen et al. 2007; Carrer and Urbinati 2004), while in central and northern Poland, the mean yearly precipitation levels vary between $550 \mathrm{~mm}$ in the central region to $650 \mathrm{~mm}$ in the north (Kirschenstein and Baranowski 2005). 

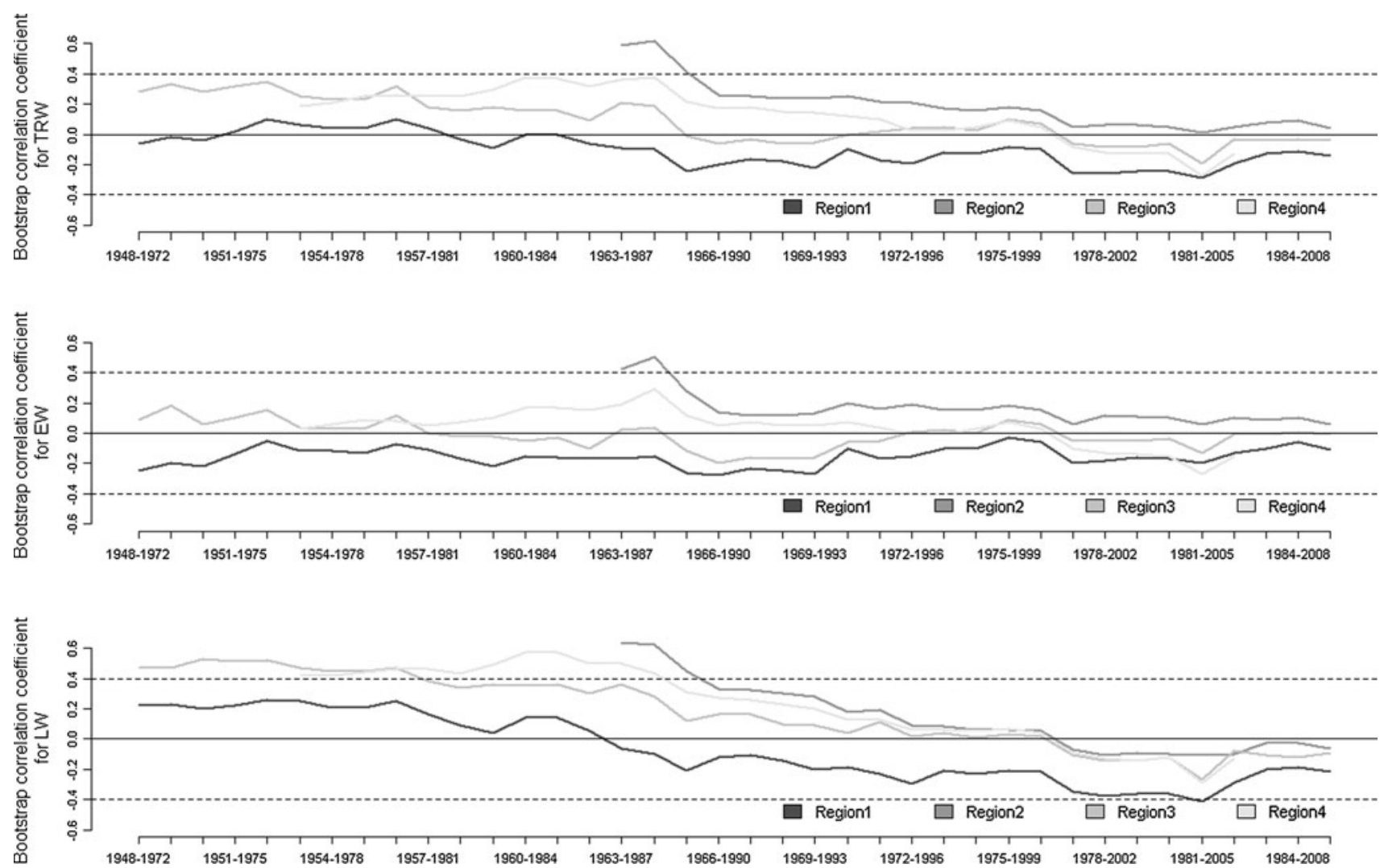

Fig. 5 Change in influence of March temperature on tree-ring widths in sequential 25-year time intervals. $T R W$ tree-ring widths, $E W$ earlywood, $L W$ latewood

Effect of increasing temperature

Most studies on the effect of increasing temperatures focus mainly the problems of climate reconstruction, and the possible implication of this phenomenon on the processes of calibration and verification (D'Arrigo et al. 2008). The longterm temperature increase during February and particularly March in Poland (Kożuchowski and Degirmendžić 2005) reflects the changing climate in Europe and might cause different seasonal reactions of tree growth to temperature. D'Arrigo et al. (2008) called this phenomenon the "divergence problem". It was observed in northern Alaskan forests where it was associated with June-July mean temperatures (D'Arrigo et al. 2008). The effect of climate change is clearly observed in regions were temperature is a limiting factor. This condition is found amongst trees growing in the European Alps (Theurillat and Guisan 2001). In this environment, larch will increase its radial growth with an increase in mean annual temperature of $2{ }^{\circ} \mathrm{C}$ and a slight increase in precipitation (Keller et al. 1997). This study extends the existing knowledge. At first, the trees grew only in the lowland, but later, forest management activities extended this range. The March temperature increase has had no impact on TRW and EW in the period 1982-2006. The width of the earlywood which accounts for between 72 and $77 \%$ of TRW is not dependent on March temperature, as shown by the moving window between 1950 and 1982 and from 1970 to 2008, where the bootstrap correlation coefficient varies from -0.2 to +0.2 (except for the period 1981-2005 in region 4) (Fig. 5). LW was reduced in region 1 between 1963 and 2009. When the bootstrap correlation coefficient is below 0 in the period 1977-2009, the width of LW makes up less than $30 \%$ of TRW (Fig. 5).

Should the European larch be introduced more widely outside its natural range?

The uncertainties in the climate change projections are often emphasised. The impact of these changes on forests remains uncertain because of an incomplete understanding of tree responses to the changing climatic factors (Lindner et al. 2008). The coniferous forests expand beyond the limits of their natural range because of forest management (Spiecker 2003). The palynological study of species distribution clearly shows no anthropogenic influenced tree migration in response to changing climate during the Holocene. A good example of this is Norway spruce, where pollen studies reveal that during the Preboreal period spruce 
had re-distribution expanded in association with the warming climate (Latałowa and van der Knaap 2006). Currently, the climate change scenario (Lindner et al. 2008) and the ecological oriented approach of forest management does not favour coniferous forests, which have been introduced on sites naturally dominated by broadleaved trees (Spiecker 2003). On the other hand, in Germany, two different climate change scenarios were tested, and coniferous species (spruce and pine) showed more positive responses than beech and oak. The scenarios differ in precipitation level, both of them represented the increase of temperature of about $+3 \mathrm{~K}$ (Lasch et al. 2002). On the basis of these findings, it is difficult to clearly decide about the introduction of coniferous trees outside their natural range.

\section{Conclusions}

In terms of changing climate variables and unpredictable changes in environment, the question of introducing new species outside their natural range is still open. One of the solutions in terms of undermining the impact of climate change on forests is increasing surface area of the forest. However, this may lead to an increase in the sensitivity of forests to changes in precipitation and high temperatures. One way to counteract this is to increase biodiversity within plantations through an increase in the number of species (multi-species plantations) (Nabuurs et al. 2007). The research presented here identifies that the observed recent increased March temperature has no significant, negative effect on tree-ring widths. However, the present visual condition of European larch together with the lack of negative response to tree growth observed with the increase in March temperature suggests that wider distribution of larch outside its natural range may be beneficial.

Acknowledgments This work was supported by the National Science Centre in the years 2011-2013, habilitation grant number N N309 7091410. I thank Martin Bridge for language correction and Werner Ulrich for discussions on the manuscript. I thank also Jerzy Miałdun for drawing maps. Special thanks I owe to the staff of The State Forests for their hospitality and help. I would like also to thank family members and friends who helped in the fieldwork. This paper is a part of the habilitation thesis.

Open Access This article is distributed under the terms of the Creative Commons Attribution License which permits any use, distribution, and reproduction in any medium, provided the original author(s) and the source are credited.

\section{References}

Bijak S (2010) Tree-ring chronology of Silver fir and its dependence on climate of the Kaszubskie Lakeland (Northern Poland). Geochronometria 35:91-94. doi:10.2478/v10003-010-0001-9
Biondi F, Waikul K (2004) DENDROCLIM2002: a C++ program for statistical calibration of climate signals in tree-ring chronologies. Comput Geosci 30:303-311. doi:10.1016/j.cageo. 2003.11.004

Bronisz A, Bijak S, Bronisz K (2010) Dendroklimatologiczna charakterystyka jodły pospolitej (Abies alba Mill.) na terenie Gór Świętokrzyskich in the Świętokrzyskie Mountains [Dendroclimatological characteristics of silver fir (Abies alba Mill.) in the Świętokrzyskie Mountains]. Sylwan 154:463-470 (abstract and summary in English)

Bunn AG (2008) A dendrochronology program library in R (dplR). Dendrochronologia 26:115-124. doi:10.1016/j.dendro.2008. 01.002

Büntgen U, Frank DC, Kaczka RJ, Verstege A, Zwijacz-Kozica T, Esper J (2007) Growth responses to climate in a multi-species tree-ring network in the Western Carpathian Tatra Mountains, Poland and Slovakia. Tree Physiol 27:689-702

Carrer M, Urbinati C (2004) Age-dependent tree-ring growth responses to climate in Larix decidua and Pinus cembra. Ecology 85:730-740

Carrer M, Urbinati C (2006) Long-term change in the sensitivity of tree-ring growth to climate forcing in Larix decidua. The New Phytol 170:861-872

Cook E, Briffa K, Shiyatov S, Mazepa A, Jones P (1990) Data analysis. In: Cook E, Kairiukstis L (eds) Methods of dendrochronology: applications in the environmental sciences, International Institute for Applied Systems Analysis. Kluwer, Dordrecht, pp 97-162

D'Arrigo R, Wilson R, Liepert B, Cherubini P (2008) On the "Divergence Problem" in Northern Forests: a review of the treering evidence and possible causes. Glob Planet Change 60:289-305. doi:10.1016/j.gloplacha.2007.03.004

Danek M (2009) Wpływ warunków klimatycznych na szerokość przyrostów rocznych modrzewia (Larix decidua Mill.) rosnącego w północnej części województwa małopolskiego [The influence of climate conditions on tree ring width of larch (Larix decidua Mill.) from the northern part of the Malopolska province]. Sylwan 153:768-776 (abstract and summary in English)

Danek M, Danek T (2011) Zastosowanie alternatywnych metod przetwarzania danych $\mathrm{w}$ analizie dendroklimatologicznej modrzewia Larix decidua Mill. z Polski południowej [Alternative methods of data processing in dendroclimatological analysis of larch Larix decidua Mill. from southern Poland]. Sylwan 155:147-158 (abstract and summary in English)

Feliksik E, Wilczyński S (2000) The influence of thermal and pluvial conditions on the radial increment of the Scots pine (Pinus sylvestris L.) from the area of Dolny Ślask. Fol For Pol Ser A $55-66$

Frank D, Esper J (2005) Characterization and climate response patterns of a high-elevation, multi-species tree-ring network in the European Alps. Dendrochronologia 22:107-121. doi: 10.1016/j.dendro.2005.02.004

Grissino-Mayer H (2001) Evaluating crossdating accuracy: a manual and tutorial for the computer program COFECHA. Tree-Ring Res 57:205-221

Igliński B, Iglińska A, Kujawski W, Buczkowski R, Cichosz M (2011) Bioenergy in Poland. Renew Sustain Energy Rev 15:2999-3007. doi:10.1016/j.rser.2011.02.037

Keller T, Guiot J, Tessier L (1997) Climatic effect of atmospheric $\mathrm{CO}_{2}$ doubling on radial tree growth in south eastern France. J Biogeogr 24:857-864. doi:10.1046/j.1365-2699.1997.00140.x

Kirdyanov AV, Treydte KS, Nikolaev A, Helle G, Schleser GH (2008) Climate signals in tree-ring width, density and $\delta 13 \mathrm{C}$ from larches in Eastern Siberia (Russia). Chem Geol 252:31-41. doi: 10.1016/j.chemgeo.2008.01.023

Kirschenstein M, Baranowski D (2005) Sumy opadów atmosferycznych w Polsce w latach 1951-1995. Badania 
Fizjograficzne nad Polską zachodnią Seria A-Geografia Fizyczna 55-72

Klein Tank AMG, Wijngaard JB, Können GP et al (2002) Daily dataset of 20th-century surface air temperature and precipitation series for the European Climate Assessment. Int J Climatol 22:1441-1453. doi:10.1002/joc.773

Koprowski M (2012) Spatial distribution of introduced Norway spruce growth in lowland Poland: the influence of changing climate and extreme weather events. Quat Int. doi: 10.1016/j.quaint.2012.04.020

Koprowski M, Gławenda M (2007) Dendrochronologiczna analiza przyrostów rocznych jodły pospolitej (Abies alba Mill.) na Pojezierzu Olsztyńskim (Nadleśnictwo Wichrowo) [Dendrochronological analysis of silver fir (Abies alba Mill.) annual tree-ring growth in the Olsztyńskie Lakeland (Wichrowo Forest District)]. Sylwan 151:35-40 (abstract and summary in English)

Koprowski M, Zielski A (2006) Dendrochronology of Norway spruce (Picea abies (L.) Karst.) from two range centres in lowland Poland. Trees Struct Funct 20:383-390. doi:10.1007/s00468006-0051-9

Koprowski M, Przybylak R, Zielski A, Pospieszyńska A (2012) Tree rings of Scots pine (Pinus sylvestris L.) as a source of information about past climate in northern Poland. Int $\mathrm{J}$ Biometeorol 56:1-10. doi:10.1007/s00484-010-0390-5

Kożuchowski K, Degirmendžić J (2005) Contemporary changes of climate in Poland: trends and variation in thermal and solar conditions related to plant vegetation. Pol J Ecol 53:283-297

Lasch P, Badeck FW, Lindner M, Suckow F (2002) Sensitivity of simulated forest growth to changes in climate and atmospheric $\mathrm{CO}_{2}$. Forstwissenschaftliches Centralblatt 121(Suppl.):155-171

Latałowa M, van der Knaap WO (2006) Late Quaternary expansion of Norway spruce Picea abies (L.) Karst. in Europe according to pollen data. Quat Sci Rev 25:2780-2805. doi:10.1016/j.quascirev. 2006.06.007

Lindner M, Seidl R, Lexer MJ, Kremer A et al (eds) (2008) AGRI2007-G4-06, Report to the European Commission DirectorateGeneral for Agriculture and Rural Development. Impacts of climate change on European forests and options for adaptation

McCarroll D, Loader NJ (2004) Stable isotopes in tree rings. Quat Sci Rev 23:771-801. doi:10.1016/j.quascirev.2003.06.017

Nabuurs GJ, Masera O, Andrasko K, Benitez-Ponce P, Boer R et al (2007) Forestry. In: Metz B, Davidson OR, Bosch PR, Dave R, Meyer LA (eds) Climate Change 2007: Mitigation. Contribution of Working Group III to the Fourth Assessment Report of the Intergovernmental Panel on Climate Change. Cambridge University Press, Cambridge
Okołowicz W, Martyn D (1984) Regiony klimatyczne. In: Atlas Geograficzny Polski. PPWK, Warszawa

Oleksyn J, Fritts H (1991) Influence of climatic factors upon tree rings of Larix decidua and L. decidua $\times$ L. kaempferi from Puławy, Poland. Trees Struct Funct 5:75-82. doi:10.1007/BF00227488

Schweingruber F (1996) Tree rings and environment. Dendroecology. Birmensdorf, Swiss Federal Institute for Forest, Snow and Landscape Research. Berne, Stuttgart

Solomon S, Qin D, Manning M, Chen Z, Marquis M, Averyt KB et al (eds) (2007) Intergovernmental Panel on Climate Change. Climate Change 2007: The Physical Science Basis. Contribution of Working Group I to the Fourth Assessment Report of the Intergovernmental Panel on Climate Change. Cambridge University Press, Cambridge

Spiecker H (2003) Silvicultural management in maintaining biodiversity and resistance of forests in Europe-temperate zone. J Environ Manage 67:55-65. doi:10.1016/S0301-4797(02)00188-3

Szychowska-Krąpiec E (2010) Long-term chronologies of pine (Pinus sylvestris L.) and fir (Abies alba Mill.) from the Małopolska Region and their paleoclimatic interpretation. Folia Quat 79:5-124

Theurillat J-P, Guisan A (2001) Potential impact of climate change on vegetation in the European Alps: a review. Clim Change 50:77-109

Vitas A, Žeimavičius K (2010) Regional tree-ring chronology of European Larch (Larix decidua Mill.) in Lithuania. Baltic For 16:187-193

Ward JH (1963) Hierarchical grouping to optimize an objective function. J Am Stat Assoc 58:236-244

Wigley TML, Briffa KR, Jones PD (1984) On the average value of correlated time series, with applications in dendroclimatology and hydrometeorology. J Clim Appl Meteorol 23:201-213

Wilczyński S, Skrzyszewski J (2002) Dependence of Scots pine tree rings on climatic conditions in Southern Poland (Carpatian Mts.). Electr J Pol Agric Univ (For) 2:1-9

Wilson RJS, Hopfmueller M (2001) Dendrochronological investigations of Norway spruce along an elevational transect in the Bavarian Forest, Germany. Dendrochronologia 19:67-79

Zielski A, Krąpiec M (2004) Dendrochronologia. Wydawnictwo Naukowe PWN, Warszawa

Zielski A, Krąpiec M, Koprowski M (2010) Dendrochronological data. In: Przybylak R, Majorowicz J, Brázdil R, Kejna M (eds) The Polish climate in the European context: an historical overview, pp 191-217. doi:10.1007/978-90-481-3167-9 